\title{
Removal of Chromium from a Tannery Wastewater by Using a Maghemite Nanoparticles
}

\author{
B. Lkhagvadulam, B. Tsagaantsetseg, D. Tergel, and S. Chuluunkhuyag
}

\begin{abstract}
This study investigates the applicability of maghemite nanoparticles (MNPs) for the removal of total chromium (TCr) from the tannery wastewater (TWW). The MNPs of $122 \mathrm{~nm}$ were synthesized using a co-precipitation method and characterized by Nanometer particle size analysis (NANOPHOX), transmission electron microscopy (TEM) and $X$-ray diffraction (XRD). Batch experiments were carried out for the removal of TCr from the TWW by MNPs. The effects of dosage of MNPs, $\mathrm{pH}$, initial concentration and contact time on TCr removal were investigated. Maximum removal efficiency of TCr in the TWW was achieved $96.7 \%$ at optimum condition (pH 2, MNPs dose was $0,5 \mathrm{~g} / \mathrm{L}$, initial concentration of $\mathrm{TCr}$ was $33,2 \mathrm{mg} / \mathrm{L}, 40$ minute) at room temperature. It is observed that the best efficiency in removing major physico-chemical parameters (TCr, SS, COD, sulfide and turbidity) in the TWW, which are well below the standard prescribed limits for MNS 6561: 2015. Thus the study suggests that the treatment with MNPs could be promising to reduce pollutants from the other TWW.
\end{abstract}

Index Terms-Maghemite nanoparticles (MNPs), tannery wastewater (TWW), total chromium (TCr), treatment.

\section{INTRODUCTION}

Tanning is the chemical process that converts animal hides and skin into leather and other related products. The transformation of hides into leather is usually done by means of tanning agents and the process generates highly turbid, colored and foul smelling wastewater [1]. Treatment of the TWW has been difficult due to their components such as BOD, COD, SS, oil-grease, sulphur, chromium (VI), TCr and $\mathrm{pH}$. These parameters pose a biological risk. Heavy metals which have been an important toxic pollutant group tend to accumulate in soils, plants and animals according to the seasonal condition and the characteristics of soil of the region. Among these metals, $\mathrm{Cr}(\mathrm{VI})$ exists especially in leather tanning industries. Also $\mathrm{Cr}(\mathrm{VI})$ has been known to have toxic effects on the activated sludge process in the wastewater treatment plant. Chromium exists in $\mathrm{Cr}$ (III) form in many biological proteins, nucleic acids and low molecules weighted ligands. Chromium (VI) form is much more toxic than chrome (III) form due to its oxidation potential and its penetration in the tissue [2]. Major $\mathrm{Cr}(\mathrm{VI})$ species include, $\mathrm{HCrO}_{4}^{-}$, chromate $\left(\mathrm{CrO}_{4}{ }^{2-}\right)$ and dichromate $\left(\mathrm{Cr}_{2} \mathrm{O}_{7}{ }^{2-}\right)$. It can

Manuscript received May 15, 2017; revised July 6, 2017. The research funding was provided by the "L2766-MON: Higher Education Reform" project financed by the Asian Development Bank and executed by the Ministry of Education, Culture, Science and Sports of Mongolia.

The authors are with the Department of Environmental Engineering, School of Civil Engineering and Architecture, Mongolian University of Science and Technology, Ulaanbaatar 14191, Mongolia (e-mail: Lkhagvadulam@must.edu.mn). cause severe damages to the human health including, but not limited to, liver and kidney damage, producing lung tumors, severe diarrhea, allergic dermatitis, skin irritation, internal hemorrhage and respiratory problems [3].

Several methods have been developed for the treatment of chromium containing wastewaters, including biological and physicochemical processes. Conventional methods for removing $\mathrm{Cr}(\mathrm{VI})$ include chemical reduction to the $\mathrm{Cr}$ (III) followed by precipitation under alkaline conditions or removal by ion exchange. Other [1], [3], [4] reported removal methods are as follows; adsorption reverses osmosis, electrochemical precipitation, bio adsorption, foam separation, separation by freezing and evaporation.

Recently, the utilization of nanomaterials for removal of heavy metals from water has arisen as an attractive research direction. This is because, compared to bulk materials, nanomaterials-based adsorbents possess much larger surface area, which can provide a greater number of active sites for interaction or adsorption. Some kinds of nanomaterials, such as carbon nanotubes, iron oxide, aluminum oxide, and titanium oxide have been used as nano-adsorbents in many studies [5]-[9] and have showed excellent adsorption capacity for various heavy metals including chromium.

Among these nano-adsorbents, the utilization of iron oxide nanomaterials has been received much attention due to their unique properties, such as high surface area-to-volume ratio, surface modifiability, excellent magnetic properties, great biocompatibility, ease of separation using external magnetic field, reusability and comparatively low cost [3].

Several studies have been conducted for aqueous $\mathrm{Cr}$ (VI) removal and magnetite NPs, MNPs and mixtures of above two NPs were extensively studied for $\mathrm{Cr}(\mathrm{VI})$ removal [3]. Hu, Chen et al. [10], [11] studied the performance and mechanism of $(\mathrm{Cr}(\mathrm{VI})$ removal form industrial wastewater, using MNPs. In these studies, 17 and $19.2 \mathrm{mg} / \mathrm{g}$ adsorption capacity were reported at $\mathrm{pH}$ 2.5. In Wenjun Jiang's study [12], $1.62 \mathrm{mg} / \mathrm{g}$ adsorption capacity was reported at $\mathrm{pH} 4$. Magnetite nanoparticles with or without functionalization agents have also been widely studied for aqueous $\mathrm{Cr}$ (VI) removal. Shen, Pan et al. [13] was done a study to remove $\mathrm{Cr}(\mathrm{VI})$ from copper and chromium co-existing water system, with amino functionalized nano sized magnetite particles. Maximum $\mathrm{Cr}(\mathrm{VI})$ uptake was reported as $370.37 \mathrm{mg} / \mathrm{g}$. In a different study, Jing $\mathrm{Hu}$ et al. [14] the $\mathrm{Cr}(\mathrm{VI})$ adsorption capacity of the $-\mathrm{FeOOH}$-coated $-\mathrm{Fe}_{2} \mathrm{O}_{3}$, was determined to be $25.8 \mathrm{mg} / \mathrm{g}$, and Thi May Do et al. [5] was determined 22.0 $\mathrm{mg} / \mathrm{g}$ for $\mathrm{Cr}(\mathrm{VI})$. Ethylenediamine-functionalized $\mathrm{Fe}_{3} \mathrm{O}_{4}$ magnetic polymers revealed adsorption capacity of 32.15 to $61.35 \mathrm{mg} / \mathrm{g}$ for $\mathrm{Cr}$ (VI) [15]. In addition to above mentioned nano-sorbents, $\mathrm{Fe}_{3} \mathrm{O}_{4} /$ carbon nanotube NPs, $\mathrm{Fe}_{3} \mathrm{O}_{4} @ \mathrm{n}-\mathrm{SiO}_{2}$ 
NPs, $\mathrm{MnO}_{2} / \mathrm{Fe}_{3} \mathrm{O}_{4} / \mathrm{o}-\mathrm{MWCNTs}$ [3], [16] of Magnetic Hydrogel [17] were also reported where adsorption capacity ranging from $2.3 \mathrm{mg} / \mathrm{g}$ to $205 \mathrm{mg} / \mathrm{g}$.

The Pre-treatment facility of Ulaanbaatar city in Mongolia is the first facility that was established in 1972 from wool scouring wastewater. This facility has the capacity to treat approximately $4,000 \mathrm{~m}^{3} /$ day wastewater using mechanical and chemical method. The facility receives and treats wastewater from 27 leather and wool washing plants. After the pretreatment, the industrial wastewater pumped to the central wastewater treatment facility. According to Mongolian standard MNS 6561:2015 (Environment. Water quality. Effluent water for sewerage network. General requirements MNS 6561:2015) [18], the recommended amount of $\mathrm{TCr}$ content in the pre-treated industrial wastewater pumped to the central wastewater treatment facility is $1.0 \mathrm{mg} / \mathrm{L}$. However, sometimes the amount of chromium content in the pre-treated water is higher than the recommended standard limit. This creates challenges for the central wastewater treatment facility by reducing the percentage of fully-treated wastewater outputs. Therefore, our main purpose was to remove toxic, TCr quantity from treated industrial wastewater by using iron oxide nanoparticles synthesizing technique.

Most of the researcher reports on aqueous Cr (VI) removal by using iron oxide NPs have focused on characterization of NPs and the effect of some factors for Cr (VI) removal and the adsorption isotherm mechanisms. Thus, in this study, MNPs has been synthesized using a co-precipitation method, characterized, applied for the removal of TCr from TWW. The TWW was characterized and treated by using MNPs. The factors possibly affecting TCr removal performance, including sample $\mathrm{pH}$ and the adsorbent dosage, the initial $\mathrm{TCr}$ concentration and contact time were examined. The adsorption capability of the synthesized MNPs for $\mathrm{TCr}$ and $\mathrm{Cr}(\mathrm{VI})$ were evaluated. Furthermore, we evaluated major physico-chemical parameters of TWW before and after the treatment.

\section{MATERIALS AND METHODS}

\section{A. Synthesis and Characterization of MNPs}

MNPs were prepared according to the literature procedures [12]. MNPs were prepared by a co-precipitation method. All solutions were purged with argon for $15 \mathrm{~min}$ to remove oxygen prior and during reaction. Iron solutions of $\mathrm{FeCl}_{2} \bullet 4 \mathrm{H}_{2} \mathrm{O}(2.0 \mathrm{~g})$ and $\mathrm{FeCl}_{3} \cdot 6 \mathrm{H}_{2} \mathrm{O}(5.4 \mathrm{~g})$ were diluted to $30 \mathrm{~mL}$ with water. The iron mixture was stirred magnetically, gently purged with argon and heated to $80{ }^{\circ} \mathrm{C}$ and then $40 \mathrm{~mL}$ of $15 \%$ diluted ammonium hydroxide solution added dropwise into the mixture over a $20 \mathrm{~min}$ time interval. The mixture was aged at $80^{\circ} \mathrm{C}$ for an additional $40 \mathrm{~min}$. The product was rinsed with water then ethanol three times. The samples were separated using a magnet and dried in a vacuum oven at $50{ }^{\circ} \mathrm{C}$ to a constant weight.

Particle size and size distribution analysis of the MNPs was done on Photon Cross Correlation Spectroscopy (PCCS) (Sympatec GmbH, Germany). The MNPs were characterized by a combination analysis of transmission electron microscopy (TEM), and X-ray diffraction (XRD). TEM images were performed on a (JEOL, JEM 2011). A typical sample for TEM was prepared by drying of a drop of the solution at room temperature on a carbon-coated copper grid. XRD was recorded on an X-ray powder diffractometer XRD (Enraf Nonius Delft) using $\mathrm{Cu} K \alpha$ radiation $(\lambda=1.54 \AA$ ).

\section{$B$. Characteristic of the TWW before and after the Adsorption Studies}

The study was conducted during March 2016 - April 2017, the samples were collected from the two main drains, in particular for sulphide and chrome-containing liquors of TWW pre-treatment facility in Ulaanbaatar city. After collecting the sample in a container it was mixed thoroughly. Test samples were separated for the container to beaker and the settle able suspension were allowed to settle. Supernatant of the sample was taken for determining COD, SS, Sulphide and $\mathrm{pH}$ [19], [20]. The $\mathrm{pH}$ of the sample was determined by using Mettler Toledo pH meter (MNS ISO 10523:2001) [21]. COD were determined by Closed Reflux, Titrimetric Method (MNS ISO 6060:2001) [22], respectively. A quantitative analysis for the determination of suspended solid (SS) was carried out by simple laboratory method (MNS ISO 11923:2001) [23]. Sulfide was determined by using MNS ISO 5597:2006 [24]. The turbidity of the sample was determined by using 2100P Turbid meter Hach [25]. TCr and $\mathrm{Cr}(\mathrm{VI})$ were measured using the spectrophotometer (V-1200 Spectrophotometer) CS 11-0037-2008 [26] and MNS ISO 11083:2001 [27]. Sample dilution was conducted before the spectrophotometer measurement, where necessary. All chemicals were used of analytical grade reagents and the experiments were performed at least three times to minimize analytical error.

\section{Adsorption Studies}

Batch adsorption studies were performed by mixing $0.5 \mathrm{~g}$ of MNPs with $50 \mathrm{~mL}$ of the sample in $100 \mathrm{~mL}$ glass vials. The adsorption on MNPs was first studied at $\mathrm{pH}$ values of 2 to 11 to investigate the effects of $\mathrm{pH}$ values on the $\mathrm{TCr}$ adsorption. $0.1 \mathrm{MHCl}$ and $0.1 \mathrm{MNaOH}$ solutions were used to adjust the $\mathrm{pH}$ values of samples. The $\mathrm{pH}$ values of samples were stable over the experiment period [28].

For effect of adsorbent dose MNPs studies, between 0.1 $-10 \mathrm{~g} / \mathrm{L}$ MNPs was added into $50 \mathrm{~mL}$ of the samples. Adsorption equilibrium studies were conducted by varying the initial concentration of $50 \mathrm{~mL}$ of samples from 6 to 33.2 $\mathrm{mg} / \mathrm{L}$ at $\mathrm{pH} 2$, respectively [12], [28], [11].

All the adsorption experiments were carried out at a room temperature of $22 \pm 2^{\circ} \mathrm{C}$ and were performed in triplicate. The $\mathrm{TCr}$ was measured using the spectrophotometer (V-1200 Spectrophotometer). The amount of the TCr and $\mathrm{Cr}$ (VI) adsorbed on the MNPs was determined by chromium mass balance, the amount of adsorbed chromium at equilibrium $q_{e}$ $(\mathrm{mg} / \mathrm{g})$ was calculated as follows: [5]

$$
q_{e}=\left(C_{o}-C_{e}\right) \frac{V}{m}
$$

where $\mathrm{Co}, \mathrm{Ce}$, are the initial and equilibrium liquid-phase concentrations of chromium respectively $(\mathrm{mg} / \mathrm{L}), V$ the 
volume of the solution (L) and $m$ the weight of the MNPs used $(\mathrm{g})$.

\section{RESULTS AND DISCUSSIONS}

\section{A. Synthesis and Characterization of MNPs}

The commonly used synthetic way of MNPs is a co-precipitation method of the iron mixture $\left(\mathrm{FeCl}_{2} \bullet 4 \mathrm{H}_{2} \mathrm{O}\right.$ and $\mathrm{FeCl}_{3} \cdot 6 \mathrm{H}_{2} \mathrm{O}$ ) using ammonium hydroxide solution [12].

The size of MNPs was investigated using Photon Cross Correlation Spectroscopy (PCCS) (Sympatec GmbH, Germany. Fig. 1 shows the Particle Size Analyzer image of the MNPs that deionized water was used in process. The MNPs have the average size of them was $122 \mathrm{~nm}$ and specific surface area was $S_{V}=49.42 \mathrm{~m}^{2} / \mathrm{cm}^{3}$. Fig. 2 shows TEM images of MNPs. The results show that the shape of them was spherical and diameters around $122 \mathrm{~nm}$ and well dispersed with no aggregation.

To investigate the structure of the MNPs, XRD pattern was measured. Fig. 3 shows the spectrum of the XRD pattern included peaks at $3.35,2.55,2.27,1.95,1.75,1.64,1.50,1.45$ and $1.37^{\circ}$ that can be assigned to the (1 10 ), (2 10$),\left(\begin{array}{ll}2 & 11\end{array}\right),(2$ 2 0), (3 1 1), (2 2 2), (400), (422), (511) and (440) planes, respectively, which have a good match with the standard diffraction pattern of JCPDS 39-1346 [29], [30]. The XRD pattern indicated that the MNPs were in the primitive cubic crystal structure in nature [31].

\section{B. Characteristic of the TWW before the Adsorption Studies}

The study was conducted during the March 2016 - April 2017 and the wastewater of the pre-treatment facility in Ulaanbaatar city was collected several times. From these samples, only two samples were determined considerable result of TWW. The analysis results of the samples before adsorption studies are shown in TABLE I. The $\mathrm{pH}$ values were 11.8 and 12.4 , which were relatively high compared to those in technical requirements for MNS 5582:2006 standard [32]. The $\mathrm{TCr}$ in the samples was 15.2 and $33.2 \mathrm{mg} / \mathrm{L}$. In addition, TCr of TWW, was measured, varied from $6 \mathrm{mg} / \mathrm{L}$ to $33 \mathrm{mg} / \mathrm{L}$ during the study. Average value of $\mathrm{TCr}$ of these samples was $15.2 \mathrm{mg} / \mathrm{L}$ and maximum value was $33.2 \mathrm{mg} / \mathrm{L}$ during the study. And the COD in the sample were 5599 and $5078 \mathrm{mg} / \mathrm{L}$ and the SS of the sample were $3900 \mathrm{mg} / \mathrm{L}$ and $1840 \mathrm{mg} / \mathrm{L}$, respectively. The sulfide in the sample was 121.0 and $44.8 \mathrm{mg} / \mathrm{L}$, respectively. And the turbidity of the samples was 1560 and 1452 NTU, respectively. The TCr, COD, SS and Sulfide values except of the $\mathrm{pH}$ values of these samples were below compared to the technical requirements for MNS 5582:2006 standard [32].

\section{Adsorption Studies}

Several factors can be affected to the adsorption process, such as solution $\mathrm{pH}$, adsorbent dosage and contact time. In addition to these factors, the NPs size and shape also affect to the adsorption performance [3]. Several researchers Wenjun Jiang et al. [12], Jing Hu et al. [10], [11] and Thi May Do et al. [5] have used the synthetically prepared wastewater for the study.

Because our objective was the wastewater treatment of the pre-treatment facility by using the MNPs, higher adsorption capacities can be obtained by optimizing above parameters in the sample. The effect some of these factors are discussed below.

\section{1) Effect of solution $\mathrm{pH}$}

The $\mathrm{pH}$ of the solution is an important parameter which controls the adsorption process. It influences the ionization of the adsorptive molecule and hence the surface charges of the adsorbent. Therefore, investigating the effect of $\mathrm{pH}$ on the adsorption is essential in adsorption experiments [3].

The experiments were carried out to find the optimum $\mathrm{pH}$ on the adsorption of $\mathrm{TCr}$ onto MNPs using different $\mathrm{pH}$ values of 2 to 11 .

Fig. 4 shows the effects of $\mathrm{pH}$ on the adsorption of $\mathrm{TCr}$ as compared to $\mathrm{MnSO}_{4}$. As observed in the graph, when $\mathrm{pH}$ of the sample was increased from 2 to 11 , the removal efficiency of TCr of MNPs was decreased from 98.4 to $86.6 \%$, but $\mathrm{MnSO}_{4}$ was increased from $69.7 \%$ to $82.4 \%$. The highest adsorption efficiency of $\mathrm{MnSO}_{4}$ was obtained at $\mathrm{pH} 9$. Previous study by Ozdemir et al. [2] using $530 \mathrm{mg} / \mathrm{L} \mathrm{MnSO}_{4}$ dose at $\mathrm{pH}$ value 9 in the wastewater sample showed about $96 \%$ removal of $\mathrm{Cr}$ (VI). In this case, because initial concentration $\mathrm{TCr}$ of the wastewater sample was relatively lower $15 \mathrm{mg} / \mathrm{L}$ and was added $10 \mathrm{~g} / \mathrm{L}$ of MNPs into it, the removal efficiency of $\mathrm{TCr}$ was relatively high than other studies [3], [11], [12]. From that graph, the highest adsorption efficiency of MNPs was obtained $98.4 \%$ at $\mathrm{pH} 2$.

Wenjun Jiang et al. [12] observed the removal efficiency of $\mathrm{Cr}(\mathrm{VI})$ increases with the decrease of $\mathrm{pH}$ to 4 at 60 minute. Jing $\mathrm{Hu}$, et al. $(2005,2006)$ [10],[11] studied the removal efficiency of $\mathrm{Cr}(\mathrm{VI})$ decreased gradually with an increase in $\mathrm{pH}$ and the maximum removal of $\mathrm{TCr}$ occurred at about $\mathrm{pH}$ 2.5.The result was qualitatively similar to our result.

This indicated that a water sample with a lower $\mathrm{pH}$ value was favorable for the protonation of sorbent surface [3], [11]. Increased protonation could result in the increase of positively charged sites, which enhanced the attractive forces between the sorbent surface and the anions with chromium. Therefore, it will result in the increase in the adsorption capacity. On the other hand, in a water sample with higher $\mathrm{pH}$, the negatively charged sites dominate and this could enhance the repulsion forces existing between the sorbent surface and the anions with chromium and therefore decrease the adsorption of anions with chromium [3].

\section{2) Effect of the adsorbent dosage}

The adsorbent dosage is another significant parameter in the examination of the adsorption capacity of an adsorbent The determination of effect of adsorbent dosage gives an idea about the minimum amount of adsorbent need to be used for adsorption process. This value is useful in the viewpoint of cost [3].

The TCr adsorption by MNPs was performed with continuous mixing on an orbit shaker at room temperature. The TCr remaining in the sample was monitored as a function of MNPs concentration and $\mathrm{pH} 2,5,7$. Experiments were run with the initial concentration of TCr in the sample at $15.2 \mathrm{~g} / \mathrm{L}$, and dosage of MNPs from 0.1 to $10.0 \mathrm{~g} / \mathrm{L}$. The effect of the dosage of MNPs on TCr adsorption is shown in the Fig. 5. The adsorption efficiency increased from 96.7 to $99.7 \%$ at 
pH 2, from 63.5 to $96.8 \%$ at $\mathrm{pH} 5$, from 32.7 to $96.4 \%$ at $\mathrm{pH}$ 7 , with increasing the amount of MNPs from $0.1 \mathrm{~g} / \mathrm{L}$ to $10 \mathrm{~g} / \mathrm{L}$. This is due to increase in surface area where the adsorption takes places [12]. At MNPs dosage $0.5 \mathrm{~g} / \mathrm{L}$, the removal efficiency of TCr in the sample was effectively increased to 98.2, 75.4, 44.4 at $\mathrm{pH} 2,5,7$, respectively. In this case, about $0.5 \mathrm{~g} / \mathrm{L}$ MNPs was enough to remove about $98.2 \%$ of TCr at initial concentration equal $15,2 \mathrm{~g} / \mathrm{L}$ wastewater sample at $\mathrm{pH}$ 2. Further, based on the adsorption studies, a concentration of $0.5 \mathrm{~g} / \mathrm{L}$ MNPs was employed for studying the initial $\mathrm{TCr}$ concentration and contact time.

Although a direct comparison of MNPs with other adsorbents dosage difficult, due to the different applied experiment conditions; especially initial concentration of $\mathrm{Cr}$ (VI), it was found, in general, that the dosage of MNPs for $\mathrm{Cr}$ (VI) using equilibrium experiments at $\mathrm{pH}$ of 2-4 and room temperature of $22-25^{\circ} \mathrm{C}$, determined to be $0.5 \mathrm{~g} / \mathrm{L}$ of MNPs is higher than those of $0.3 \mathrm{~g} / \mathrm{L}$ (initial concentration of $\mathrm{Cr}(\mathrm{VI})$ was 500ppb) by Wenjun Jiang et al. [12]. And it is lower than $5 \mathrm{~g} / \mathrm{L}$ of MNPs (initial concentration of $\mathrm{Cr}(\mathrm{VI})$ was $50 \mathrm{mg} / \mathrm{L}$ and the removal efficiency was found $97.3 \%$ by Jing $\mathrm{Hu}$, et al. 2005 [10] and [11], respectively. And the above dosage $0.5 \mathrm{~g} /$ $\mathrm{L}$ is higher than $150 \mathrm{mg} / \mathrm{L}$ of $\mathrm{FeCl}_{3}$ coagulant (initial concentration of $\mathrm{Cr}(\mathrm{VI})$ was $9.8 \mathrm{mg} / \mathrm{L}$ and the removal efficiency was found $96 \%$ by Manjushree Chowdhury et al. [20].

\section{3) Effect of the initial TCr concentration and contact time on TCr adsorption}

The study was conducted during 2016-2017 and at that time $\mathrm{TCr}$ concentration of TWW incoming the pre-treatment facility was between 6.3-33.2mg/l. Maximum concentration of $\mathrm{TCr}$ was $33.2 \mathrm{mg} / \mathrm{l}$. Therefore, our main purpose was to find an optimum solution for the wastewater outputs from the pre-treatment facility. Previously, other researchers conducted this experiment in the synthetic solutions $\mathrm{Cr}(\mathrm{VI})$ [5], [10], [11], [12].

The concentration of TCr in the wastewater samples vs. the adsorption time at various initial concentrations of $\mathrm{TCr}$ is illustrated in Fig. 6. Experiments were run with the initial concentration of $\mathrm{TCr}$ from $6.3-33.2 \mathrm{mg} / \mathrm{L}$, while varying the contact time from 0 to $120 \mathrm{~min}$, and dosage of MNPs $0.5 \mathrm{~g} / \mathrm{L}$ at $\mathrm{pH}$ 2. The adsorption of TCr by MNPs was rapid in the first 10 min followed by a slow $\mathrm{TCr}$ adsorption stage at longer contact times as illustrated in Fig. 6.

The concentration of $\mathrm{TCr}$ in the samples at equilibrium gradually increases with increases in the initial concentration of TCr. After 10 minute, the observed removal efficiency of TCr by MNPs at initial TCr concentration of 6.3, 10.8, 15.2, $22.5,28.5$ and $33.2 \mathrm{mg} / \mathrm{l}$ were $98.6 \%, 98.4 \%, 98.2 \%, 90.3 \%$, $84.3 \%$ and $77.4 \%$, respectively. Under these experimental conditions, the removal efficiency of $\mathrm{TCr}$ modestly decreased as a function of the increase in initial concentrations of TCr. Chromium ions were adsorbed onto MNPs rapidly, and equilibrium was established at 40 minutes. After 40 minute, the observed removal efficiency of TCr by MNPs at initial TCr concentration of $6.3,10.8,15.2,22.5$, 28.5 and $33.2 \mathrm{mg} / \mathrm{l}$ were $99.7 \%, 99.5 \%, 99.3 \%, 97.5 \%$, $96.1 \%$ and $96.7 \%$, respectively.

The results shown in Fig. 6 and Table II indicate that the
TCr adsorption capacity reached $62.4 \mathrm{mg} / \mathrm{g}$ within $40 \mathrm{~min}$ at $\mathrm{TCr}$ concentrations of $33.2 \mathrm{mg} / \mathrm{L}$. And the $\mathrm{Cr}(\mathrm{VI})$ adsorption capacity reached $8.04 \mathrm{mg} / \mathrm{g}$ within $40 \mathrm{~min}$ at $\mathrm{Cr}(\mathrm{VI})$ concentrations of $4.6 \mathrm{mg} / \mathrm{L}$. This might be due to the fixed amount of MNPs, meaning that the number of available active sites for adsorption was kept constant. Thus, no more increase in the adsorption efficiency was observed above $33.2 \mathrm{mg} / \mathrm{L}$.

Few studies have been conducted for aqueous $\mathrm{Cr}$ (VI) removal and adsorption capacities of some of the MNPs. Hu, Chen et al. [10], [11] and Wenjun Jiang et al. [12] studied the performance and mechanism of different heavy metals (Cr(VI), $\mathrm{Cu}(\mathrm{II})$, and $\mathrm{Ni}(\mathrm{II})$ ) removal from industrial wastewater and $\mathrm{Cr}$ (VI) from drinking water using MNPs. When comparison with other MNPs adsorbents capacity, that the adsorption capacity of MNPs our prepared is higher than those of $1.62 \mathrm{mg} / \mathrm{g}$ at $\mathrm{pH} 4$ for $\mathrm{Cr}$ (VI) by Wenjun Jiang et al. [12] and it is below than $17 \mathrm{mg} / \mathrm{g}$ and $19.2 \mathrm{mg} / \mathrm{g}$ by Jing $\mathrm{Hu}$ et al. [10], [11] for Cr (VI), respectively.

The rapid adsorption of metals is perhaps due to external surface adsorption. Since nearly all of the adsorption sites of MNPs exist on the exterior of the adsorbent compared to the porous adsorbent, it is easy for the adsorbent to access the active sites; hence, a rapid approach to equilibrium. This result is encouraging, as the equilibrium time is one of the important engineering parameters for an economical wastewater treatment plant [11].

\section{Characteristic of the TWW after the Adsorption Studies}

Turbidity, odor and appearance: The color appearance of untreated wastewater was found bluish green. The odor was found very pungent smell in untreated effluent and unobjectionable odor was observed after the treatment with MNPs. In Fig. 7 and TABLE III, the reduction in turbidity of the TWW was showed. Initially the turbidity of the wastewater was found to be 1452 NTU, which was higher than the previous studies [33], [34]. After treating the wastewater with MNPs the turbidity was reduced to 9.5 NTU, which was 152 times below than the untreated wastewater value.

TCr: The TCr value of the untreated and treated wastewater were 33.2 and $1.09 \mathrm{mg} / \mathrm{l}$, respectively (TABLE III), which the TCr value of the untreated wastewater was higher than the previous studies [12], [20], [33] and which was lower than the other previous studies same with MNPs [10], [35], [11]. The results shown in Fig. 7. and TABLE III indicate that after 40 minute, the removal efficiency of $\mathrm{TCr}$ by MNPs was $96.7 \%(1.09 \mathrm{mg} / \mathrm{L})$ and the value was well below the standards permissible limits of MNS 6561:2015. If initial concentration $\mathrm{TCr}$ in the untreated wastewater was increased to higher $33 \mathrm{mg} / \mathrm{l}$, in the treatment by MNPs the value of $\mathrm{TCr}$ may be higher than the standard MNS 6561:2015 [18].

$\mathrm{pH}$ : The $\mathrm{pH}$ value of the untreated and treated wastewater were 12.4 and 2.85, respectively (TABLE III). Before the treatment, $\mathrm{pH}$ value of the untreated wastewater was highly alkali, which was similar to the previous studies [36] and also was higher than the other previous studies [20], [33], [35]. After treatment by MNPs, $\mathrm{pH}$ value of the treated wastewater was highly acidic. Similar observation was reported by 
Wenjun Jiang et al. [12] that the maximum removal of $\mathrm{TCr}$ occurred at $\mathrm{pH} 4$ and Jing Hu et al. [10], [11] the maximum removal of TCr occurred at about $\mathrm{pH} 2.5$. Therefore, after the treatment, the treated wastewater must be neutralized.

SS: The SS value of the untreated and treated wastewater were 1840 and $51,0 \mathrm{mg} / \mathrm{L}$, respectively. Before the treatment, SS value of the untreated wastewater was similar to the previous studies [33] and which was lower than the other previous studies [20], [36]. After 40 minutes, the removal efficiency of SS by MNPs was $97.2 \%$, which were well below the recommended standard limits of MNS 6561:2015 [18].

COD: The COD value of the untreated and treated wastewater were 5078 and $564 \mathrm{mg} / \mathrm{L}$, respectively (TABLE III). Before the treatment, COD value of the untreated wastewater was similar to the previous studies [20] and which was higher than the other previous studies [33]. After 40 minutes, the removal efficiency of COD by MNPs was $88.9 \%$, which were well below the recommended standard limits of MNS 6561:2015 [18].

Sulfide: The sulfide value of the untreated and treated wastewater were 44.8 and $3.4 \mathrm{mg} / \mathrm{L}$, respectively. Before the treatment, sulfide value of the untreated wastewater was lower than the other previous studies [33], [36]. After 40 minutes, the removal efficiency of sulfide by MNPs was $92.4 \%$, which were well below the recommended standard limits of MNS 6561:2015 [18].

\section{CONCLUSION}

Magnetic MNPs were synthesized by a co-precipitation method, characterized and employed for TCr removal. The adsorption studies illustrated that the MNPs were very effective for the removal of TCr from TWW. Maximum removal efficiency of TCr in the TWW was achieved $96.7 \%$ at an optimum condition $(\mathrm{pH} 2$, MNPs dose was $0.5 \mathrm{~g} / \mathrm{L}$, initial concentration of $\mathrm{TCr}$ was $33.2 \mathrm{mg} / \mathrm{L}, 40$ minutes) at room temperature. It is observed that the best efficiency in removing major physico-chemical parameters (TCr, SS, COD, sulfide and turbidity) in the TWW, which are well below the recommended standard limits for MNS 6561:2015. Thus the study suggests that the treatment with MNPs could be promising in order to reduce pollutants from the other TWW.

TABLE I: CHARACTERISTICS OF UNTREATED WASTEWATER AND COMPARE WITH STANDARD TECHNICAL REQUIREMENTS

\begin{tabular}{lllll}
\hline \hline & & & & \\
Parameters & Units & Sample 1 & Sample 2 & $\begin{array}{c}\text { MNS } \\
5582: 2006[32] .\end{array}$ \\
\hline $\mathrm{pH}$ & - & 11.8 & 12.4 & 9 \\
$\mathrm{TCr}$ & $\mathrm{mg} / 1$ & 15.2 & 33.2 & 100 \\
$\mathrm{COD}$ & $\mathrm{mg} / 1$ & 5599 & 5078 & 6200 \\
$\mathrm{SS}$ & $\mathrm{mg} / \mathrm{l}$ & 3900 & 1840 & 5500 \\
Sulfide & $\mathrm{mg} / 1$ & 121.0 & 44.8 & 150 \\
Turbidity & $\mathrm{mg} / 1$ & 1560 & 1452 & - \\
\hline \hline
\end{tabular}

TABLE II: ADSORPTION CAPACITY AND INITIAL CONCENTRATION OF TWW

\begin{tabular}{llll}
\hline $\begin{array}{l}\mathrm{Co}, \mathrm{TCr} \\
(\mathrm{mg} / \mathrm{l})\end{array}$ & $\begin{array}{l}\mathrm{Co}, \mathrm{Cr}(\mathrm{VI}) \\
(\mathrm{mg} / \mathrm{l})\end{array}$ & $\begin{array}{l}\text { Qe,TCr } \\
(\mathrm{mg} / \mathrm{g})\end{array}$ & $\begin{array}{l}\text { Qe,Cr}(\mathrm{VI}) \\
(\mathrm{mg} / \mathrm{g})\end{array}$ \\
\hline 6.3 & 1.2 & 12.56 & 2.36 \\
10.8 & 3.6 & 21.49 & 7.18 \\
15.2 & 3.2 & 30.18 & 6.26 \\
22.5 & 3.7 & 43.87 & 4.84 \\
28.8 & 4.3 & 55.35 & 7.86 \\
33.2 & 4.6 & 62.21 & 8.04 \\
\hline \hline
\end{tabular}

TABLE III: CHARACTERISTICS OF TWW AND TREATED WASTEWATER COMPARED WITH STANDARD PERMISSIBLE LIMITS

\begin{tabular}{lllll}
\hline \hline Parameters & Units & $\begin{array}{l}\text { Untreated } \\
\text { Sample 2 }\end{array}$ & $\begin{array}{l}\text { Treated } \\
\text { Sample 2* }\end{array}$ & $\begin{array}{l}\text { MNS } \\
6561: 2015[18]\end{array}$ \\
\hline $\mathrm{pH}$ & - & 12.4 & 2.85 & $6-9$ \\
$\mathrm{TCr}$ & $\mathrm{mg} / 1$ & 33.2 & 1.09 & 1 \\
$\mathrm{COD}$ & $\mathrm{mg} / 1$ & 5078 & 564 & 800 \\
$\mathrm{SS}$ & $\mathrm{mg} / 1$ & 1840 & 51.0 & 400 \\
Sulfide & $\mathrm{mg} / 1$ & 44.8 & 3.4 & 5 \\
Turbidity & $\mathrm{mg} / 1$ & 1452 & 9.5 & - \\
\hline \hline
\end{tabular}

*(0.5 g/L MNPs, pH 2, 40 minute $)$

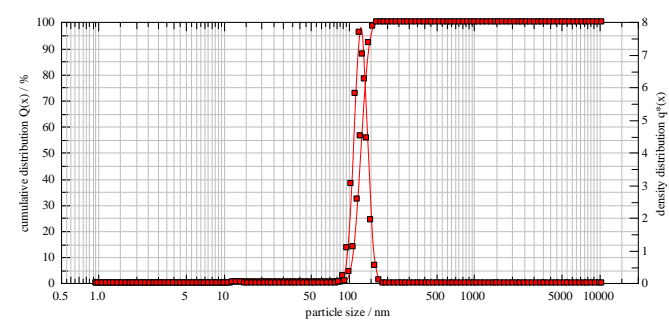

Fig. 1. Particle size analyzer image of MNPs.

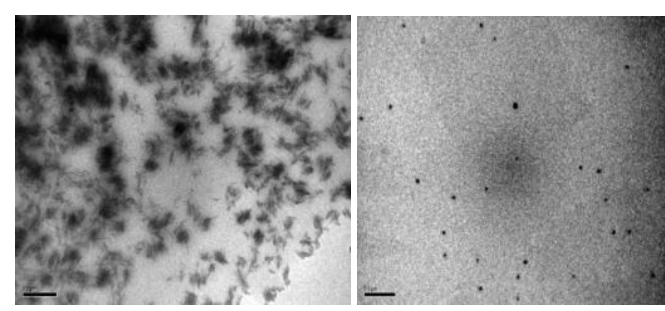

Fig. 2. TEM image of MNPs in deionized water.

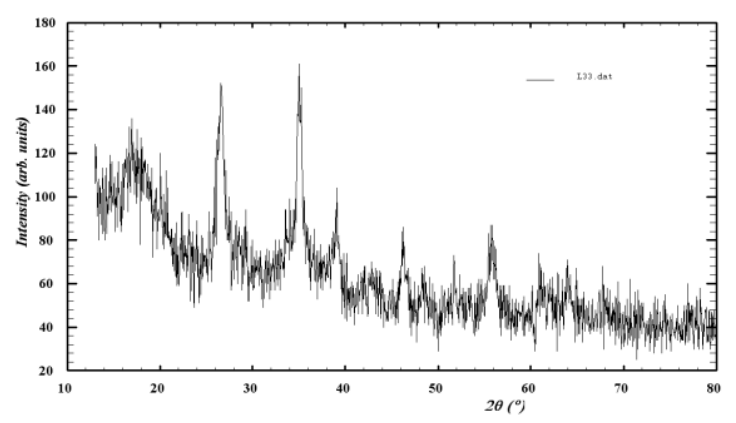

Fig. 3. XRD patterns of MNPs.

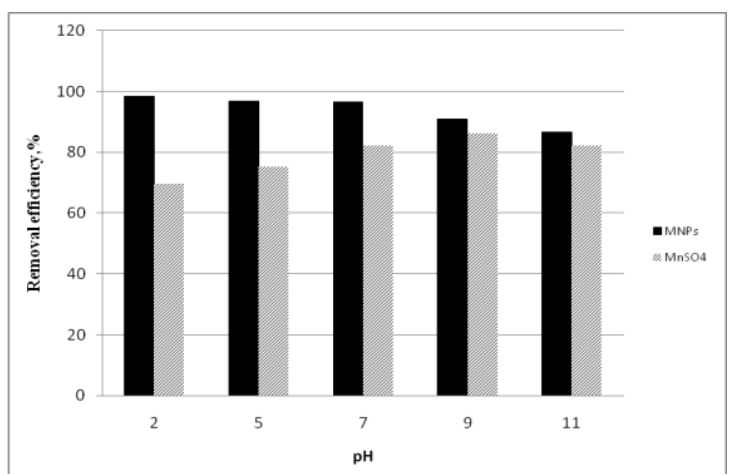

Fig. 4. Effect of $\mathrm{pH}$ on $\mathrm{TCr}$ adsorption (MNPs, $\mathrm{MnSO}_{4} 10 \mathrm{~g} / \mathrm{l}$, initial concentration $\mathrm{TCr}$ was $15 \mathrm{mg} / 1,10$ minute) 


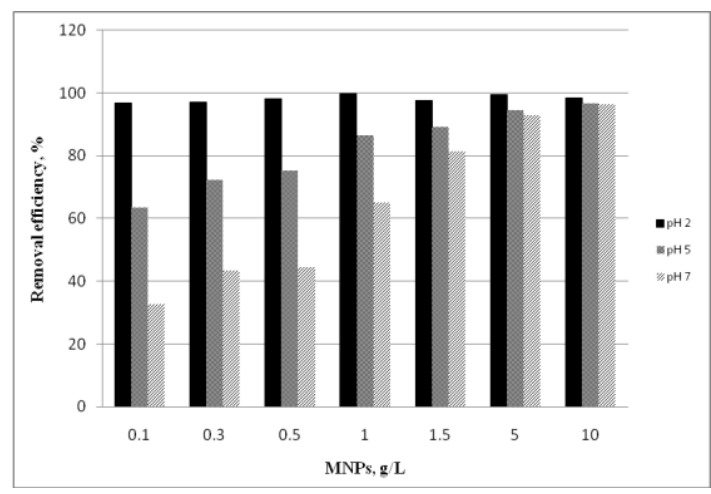

Fig. 5. Effect of the dosage of MNPs on TCr adsorption (initial concentration TCr was $15 \mathrm{mg} / \mathrm{l}, 10$ minute).

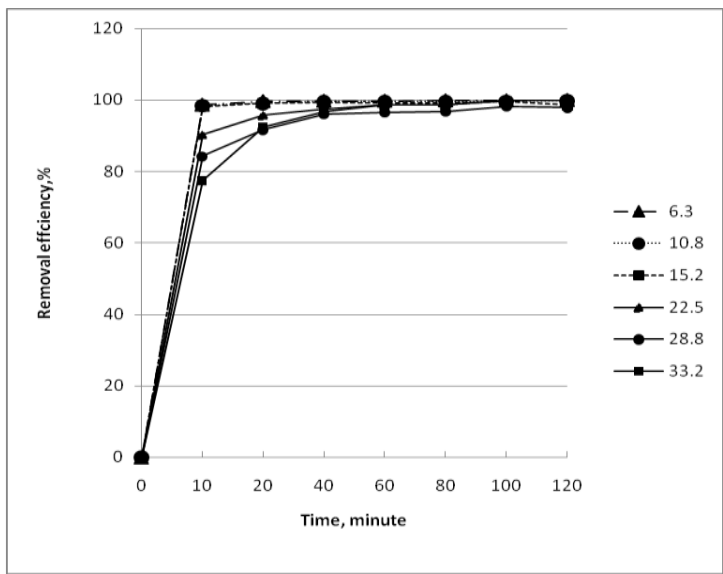

Fig. 6. Effect of the initial concentration $\mathrm{TCr}(\mathrm{mg} / \mathrm{l})$ and contact time on $\mathrm{TCr}$ adsorption.

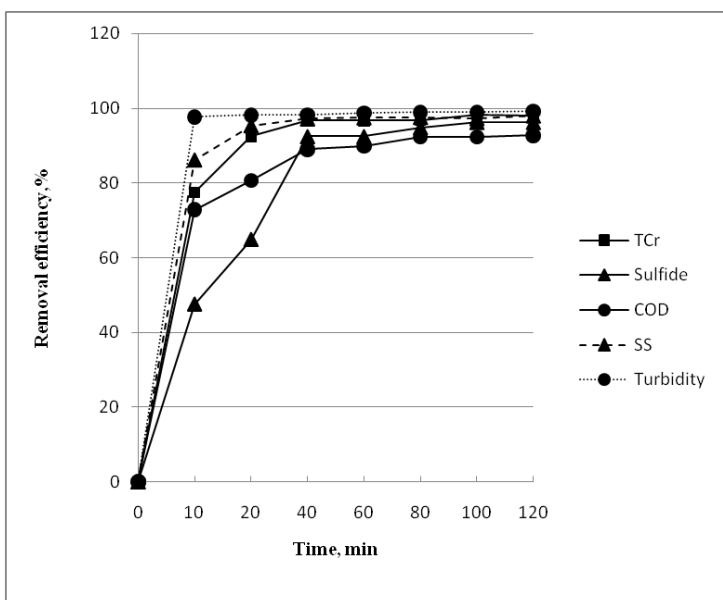

Fig. 7. Effect of time on removal percentage (\%) of some physico-chemical parameters (Sample 2, pH 2, MNPs $0.5 \mathrm{~g} / \mathrm{L}$ ).

\section{ACKNOWLEDGMENT}

The authors thank to the Department of Environmental Engineering, School of Civil Engineering and Architecture, Mongolian University of Science and Technology and the research funding of the "L2766-MON: Higher Education Reform" project financed by the Asian Development Bank and executed by the Ministry of Education, Culture, Science and Sports of Mongolia.

\section{REFERENCES}

[1] H. Dargo and A.Ayalew, "Tannery waste water treatment: A review," International Journal of Emerging Trends in Science and Technology, vol. 01, no 09, pp. 1488-1494, 2014.
[2] C. Ozdemir, M. Karatas, S. Dursun, and M. Argun, "Effect of $\mathrm{MnSO}_{4}$ on the chromium removal from the leather industry wastewater," Environ Technol, vol. 4, no. 26, pp. 397-400, 2005.

[3] NirmalaIlankoon, "Use of iron oxide magnetic nanosorbents for $\mathrm{Cr}$ (VI) removal from aqueous solutions: A review," Journal of Engineering Research and Applications, vol. 4, no. 10, pp.55-63, October 2014.

[4] L. Giusy, M. Sureyya, E. Z. G. E. Zengin, D. O. G. Lofrano, S. Meriç, G. E. Zengin, and D. Orhon, "Chemical and biological treatment technologies for leather tannery chemicals and wastewaters: A review," Science of the Total Environment, pp. 461-462, 265-281, 2013.

[5] T. M. Do and Y. J. Suh, "Removal of aqueous Cr(VI) using magnetite nanoparticles synthesized from a low grade iron ore," Particle and Aerosol Research Par. Aerosol Res. vol. 9, no. 4, pp. 221-230, December 2013.

[6] M. Hua, S. Zhang, B. Pan, W. Zhang, L. Lv, and Q. Zhang, "Heavy metal removal from water/wastewater by nano sized metal oxides: A review," Journal of Hazardous Materials., pp. 211-212, 317-331, 2012.

[7] D. Mohan and C. U. Pittman, "Activated carbons and low cost adsorbents for remediation of tri- and hexavalent chromium from water," Journal of Hazard Materials, pp. 762-811, 2006.

[8] X. Wang and Y.-F. Guo, "Nanomaterials as sorbents to remove heavy metal ions in wastewater treatment farage et al," Journal of Environment Anal Toxicol, vol. 2, no. 7, 2012.

[9] X.-L. Qu and J. J. Pedro, “Applications of nanotechnology in water and wastewater treatment," Water research, pp. 3931-3946, 2013.

[10] J. Hu, G. Chen, and M. C. L. Irene, "Removal and recovery of Cr(VI) from wastewater by maghemite nanoparticles," Water Research, vol. 39, no.18, pp. 4528-4536, November 2005.

[11] J. Hu, G. Chen, and M. C. Lo. Irene, "Selective removal of heavy metals from industrial wastewater using maghemite nanoparticle: Performance and mechanisms," MASCE. Journal of Environmental Engineering, vol. 132, no. 7, pp. 709-715, 2006.

[12] W. Jiang and M. Pelaez, "Chromium(VI) removal by maghemite nanoparticles," Chemical Engineering Journal, no. 222, pp. 527-533, 2013.

[13] H Shen, S. Pan, Y. Zhang, X. Huang, and H. Gong, "A new insight on the adsorption mechanism of amino-functionalized nano-Fe3O4 magnetic polymers in $\mathrm{Cu}(\mathrm{II}), \mathrm{Cr}(\mathrm{VI})$ co-existing water system," Chemical Engineering Journal, no. 183, pp. 180-191, 2012.

[14] J. Hu, M. C. L. Irene, and G. Chen, "Performance and mechanism of chromate (VI) adsorption by-FeOOH-coated maghemite $\left(\mathrm{Fe}_{2} \mathrm{O}_{3}\right)$ nanoparticles, Separation and Purification Technology," no. 58, pp. 76-82, 2007.

[15] Z. Yong-Ganga, S. Hao-Yua, P. Sheng-Dong, and H. Mei-Qin, "Synthesis, characterization and properties of ethylenediamine-functionalized $\mathrm{Fe}_{3} \mathrm{O}_{4}$ magnetic polymers for removal of Cr(VI) in wastewater," Journal of Hazardous Materials., no. 182, pp. 295-302, 2010.

[16] P. Xu, G. M. Zeng, D. L. Huang, C. L. Feng, S. Hu, M. H. Zhao, C. Lai, Z. Wei, C. Huang, G. X. Xie, and Z. F. Liu, "Use of iron oxide nanomaterials in wastewater treatment: A review," Science of the Total Environment, vol. 424, pp. 1-10, 2012.

[17] S. C. N. Tang, P. Wang, K. Yin, and M. C. Lo. Irene, "Synthesis and application of magnetic hydrogel for $\mathrm{Cr}(\mathrm{VI})$ removal from contaminated water," Environmental Engineering Science, vol. 27, no. $11,2010$.

[18] Environment. Water Quality. Effluent Water for Sewerage Network. General Requirements, MNS 6561, 2015.

[19] M. Kothiyal, M. Kaur, and A. Dhiman, "A comparative study on removal efficiency of Sulphide and COD from the tannery effluent by using oxygen injection and aeration," Int. J. Environ. Res, vol. 10, no. 4, pp. 525-530, ISSN: 1735-6865, Autumn 2016.

[20] M. Chowdhury, M.G. Mostafa, T. K. Biswas, and A. K. Saha, "Treatment of leather industrial effluents by filtration and coagulation processes," Water Resources and Industry, vol. 3, pp. 11-22, 2013.

[21] Water Quality. Determination of pH, MNS ISO 10523:2001.

[22] Environment. Water Quality. Determination of the Chemical Oxygen Demand, MNS ISO 6060:2001.

[23] Environment. Water Quality. Determination of Suspended Solids by Filtration through Glass-Fiber Filters, MNS ISO 11923:2001.

[24] Leather. The Leather Processing Industry. Determination of Sulfide in the Technological Waste Water, MNS 5597:2006

[25] Hach Company, Portable Turbidimeter. Model 2100P Instrument and Procedure Manual. CAT. NO. 46500-88

[26] Environment. Water Quality. Determination of Total Chromium -Spectrometric Method, CS 11-0037-2008. 
[27] Environment. Water quality. Determination of chromium (VI) -Spectrometric method using 1.5 diphenylcarbazide, MNS ISO 11083: 2001.

[28] Z. Cheng and A. L. K. Tan, "Synthesis and characterization of iron oxide nanoparticles and applications in the removal of heavy metals from industrial wastewater," International Journal of Photoenergy, Article ID 608298, p. 5, 2012.

[29] W. Cheng et al., "One-step synthesis of super para magnetic monodisperse porous $\mathrm{Fe}_{3} \mathrm{O}_{4}$ hollow and core-shell spheres," J. Mater. Chem., no. 20, pp. 1799-1805, 2010.

[30] W. S. Peternele, V. M. Fuentes, M. L, Fascineli, J. R. Silva, R. C. Silva, C. M. Lucci, and R. B. de Azevedo, "Experimental investigation of the coprecipitation method: An approach to obtain magnetite and maghemite nanoparticles with improved properties," Hindawi Publishing Corporation Journal of Nanomaterials, Article ID 682985 p. 10, 2014.

[31] M. Nazari, N. Ghasemi, H. Maddah, and M. M. Motlagh, "Synthesis and characterization of maghemite nano powders by chemical precipitation method," Journal of Nano Structure Chemstry, vol. 4, p. 99, 2014.

[32] Water Quality. The Raw Waste from the Leather Processing Industry before the Primary Effluent Treatment Plant, Technical requirements MNS 5582:2006.

[33] M. Swathi, S. Singh, S. Aravind, A. P. K. Sudhakar, R. Gobinath, D. Saranya, "Experimental studies on tannery wastewater using cactus powder as an adsorbent," Int. Journal of Applied Sciences and Engineering Research, vol. 3, no. 2, 2014.

[34] A. I. Zouboulis, P. Samaras, A. Ntolia, and K. Goudoulas, "Study of tannery wastewater treatment in a leather industry of the area of Kastoria".

[35] G. Lofrano and V. Belgiorno, "Toxicity reduction in leather tanning wastewater by improved coagulation flocculation process," Global NEST Journal, vol. 8, no. 2, pp. 151-158, 2006.

[36] B. I. Islam, A. E. Musa, E. H. Ibrahim, A. A. S. Sharafa , and B. M. Elfaki, "Evaluation and characterization of tannery wastewater," Journal of Forest Products \& Industries, vol. 3, no. 3, pp. 141-150, 2014.

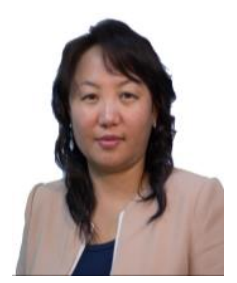

Byambajav Lkhagvadulam was born at Ulaanbaatar, Mongolia on August 20, 1975. She got the bachelor and the master degree of chemical engineering from the Department of Chemistry Engineering, National University of Mongolia, 1997 and 1999, and the PhD degree from Graduate School of Department of Nano Systems Engineering, Inje university of South Korea, 2012 .

She is an assistant professor and a senior lecturer at the Department of Environmental Engineering, School of Civil Engineering and Architecture, The Mongolian University of Science and Technology. Her current research interest is treatment technology of drinking and wastewater and solid waste. Mrs. Lkhagvadulam is the member of Global Water Partnership since 2013.

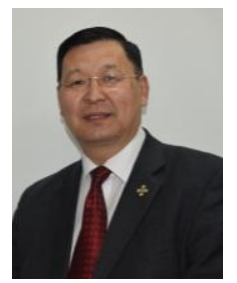

Sangi Chuluunkhuyag is a professor at the Mongolian University of Science and Technology in the Environmental Engineering Department, within the School of Civil Engineering and Architecture.

Prof. Chuluunkhuyag was born in May,1960 in Uvurhangai province of Mongolia. He graduated with his Master's Degree from the Technical University of Irkutsk, Russia in Civil Engineering in 1984, and received his Doctor's Degree in Technical Sciences from Mongolian State University in 1995.

He worked as a water engineer at the Institute of Water Policy between 1984-1986 and Russian Mongolian Joint Venture Construction Company "SOT3" between 1986-1992. He has also worked asalecturer at the Institute of Technical University of Mongolia and also been thehead of project "Natural Zeolites" at the University of Scientific and Technology of Mongolia between 1992-2002. He was the Director of the department of Administration, Evaluation and Information of the Ministry for Nature and Environment from 1999 until 2001; and been Vice Director at the Strategically Planning and Management Department of the Ministry for Nature and Environment between 2001-2002. Since 2002 until present, he has worked as a professor at the Mongolian University of Science and Technology in the department of Environmental Engineering, within the School of Civil Engineering and Architecture. His current Research Interest is ofStudying human and climate impacts on water quality and chemical composition for the streams (Forest deficiency, deforestation, permafrost melt, vegetation, biological diversity, climate change, water regime) and water and waste water treatment plants.

Prof. Chuluunkhuyag is member of Mongolian National Academy of Science and is head of Mongolian National Water Association from 1995 to present.

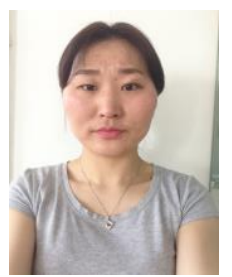

Byambatsogt Tsagaantsetseg was born in Khovd province on February 4, 1992. She received her bachelor degree in chemical engineering from Mongolian University of Science and Technology in 2013. Her topic for a Bachelor's thesis was "Alkaloids of Datura Stramonium L". She is a graduate student majoring in Water supply and sewerage engineering in the Environmental Engineering Department within the School of Civil Engineering and Architecture at The Mongolian University of Science and Technology. She is currently working as a researcher in Water Supply and Sewerage Authority Central Water Laboratory. Tsagaantsetseg was named as a top officer of the organization in 2016.

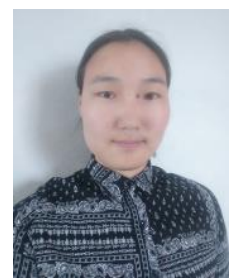

Dalantai Tergel was born on January 1, 1994. She received the degree of bachelor of environmenta engineering in environmental engineering, Mongolian University of Science and Technology, 2016. Her bachelor degree thesis defended on the topic "Project of Mechanical Treatment Facility of Municipal Solid Waste in Ulaanbaatar city of Mongolia".

She worked as office assistant in "Biodiversity and Adaptation to Climate Change NO 201265511 " project of Ministry of Environment and Green Development of Mongolia for 5 months in 2016. She published "Sludge characteristic and treatment study of Sewage treatment facility" in "Sustainable development and waste 2016" conference compilation.

Ms. Tergel's research area is the synthesis of nanoparticles and it's using for water treatment technology. 